\title{
In vitro antioxidant, antiglycation, and MGO scavenging effects of Leonurus sibiricus water extract
}

\author{
Xiu Qing Chong ${ }^{a}$, Kirtani AP Anamalay ${ }^{a}$, Okechukwu Patrick Nwabueze ${ }^{b^{*}}$, Hor Kuan Chan ${ }^{a^{*}}$ \\ ${ }^{a}$ Department of Biotechnology, Faculty of Applied Sciences, UCSI University, No. 1, Jalan Menara Gading, UCSI Heights, (Taman \\ Connaught) Cheras, 56000, Kuala Lumpur, Malaysia \\ ${ }^{b}$ Department of Food Science with Nutrition, Faculty of Applied Sciences, UCSI University, No. 1, Jalan Menara Gading, UCSI Heights, \\ (Taman Connaught) Cheras, 56000 Kuala Lumpur, Malaysia
}

Received 3rd July 2021 / Accepted 5th November 2021

\begin{abstract}
Recently, extensive research has been conducted to evaluate the inhibitory activity of different plant species on the advanced glycation end products (AGEs). L. sibiricus is a traditional herb that has been used for postpartum confinement meals in Sarawak, Malaysia and pharmacologically possess antihemorrhagic, antioxidant, anti-diabetic, and anti-cancer. The aim of this research was to evaluate the antioxidant, anti-AGEs, and preliminary biochemical screening of bioactive component present in $L$. sibiricus in water extract. Free radical scavenging activity of $L$. sibiricus was evaluated via DPPH, hydroxyl radical, nitric oxide, lipid peroxidation, chelating capacity, and total phenolic content was evaluated comparing with gallic acid. Inhibition of formation AGEs by L. sibiricus was evaluated using BSA-MGO, BSA-glucose and MGO scavenging assays. Flavonoids, phenols, saponins, alkaloids, phytosterol, and diterpenoids were identified in L. sibiricus extract. It also seems to inhibit early and late formation of AGE and MGO scavenging ability. L. sibiricus was able to inhibit the formation of early and late formation of AGE through the scavenging of the formation of reactive dicarbonyl intermediates and reduce the formation of methylquinoxaline adducts through the scavenge of MGO. The inhibition of AGEs formation by $L$. sibiricus maybe due its antioxidant property and the presence phytochemical bioactive constituents which has been previously reported to possess antioxidant and anti-AGE activity. Future research is ongoing to identify the adducts formed because of MGO scavenging by L. sibiricus using HPLC.
\end{abstract}

Keywords: AGEs, antioxidants, BSA-glucose, BSA-MGO, L. sibiricus

\section{INTRODUCTION}

Advanced glycation end products (AGEs) are formed when non-enzymatic glycation and oxidation happens between aldose sugar and modified amino groups and lipids. Formations of AGEs occur via endogenous and exogenous. Endogenous AGEs are the normal consequences of body metabolism while exogenous AGEs are derived from the non-enzymatic saccharification. This process is also known as Maillard reactions of reducing sugars on proteins or lipids when heat is applied (Yamagishi et al., 2015). Early glycation and oxidation processes induce the formation of unstable Schiff bases and Amadori products. Formation and rearrangement of Amadori products leads to the accumulation of reactive dicarbonyl intermediates ( $\alpha$-dicarbonyls or oxoaldehydes), such as methylglyoxal (MGO), glyoxal, and 3-deoxyglucosone (3-DG) (Qais et al., 2019), In the advanced stage, free radicals and reactive dicarbonyl compounds will form into isomers, respectively with arginine and lysine residues of proteins to form AGEs (Brings et al.,

*Author for correspondence: Okechukwu Patrick Nwabueze, Department of Biotechnology, Faculty of Applied Sciences, UCSI University, Malaysia; Hor Kuan Chan, Department of Food Science with Nutrition, Faculty of Applied Sciences, UCSI University, Malaysia.

Email-patrickn@ucsiuniversity.edu.my ; hkchan@ucsiuniversity.edu.my 
2017). Oxidative stress, hyperglycemia, aging, smoking can promote the formation of AGEs, and vice versa (Vlassara and Uribarri, 2013). Interaction between AGEs and receptor of AGE (RAGE) also promote the productions of other free-radicals, such as hydrogen peroxide $\left(\mathrm{H}_{2} \mathrm{O}_{2}\right)$, superoxide ion radicals $\left(\mathrm{O}_{2 \cdot}-\right)$, hydroxyl radical $(\mathrm{OH}-)$, and nitric oxide (NO) (Cepas et al., 2020). Elevation of oxidative stress due to free radical accumulation which will induce inflammatory mediators and damage protein molecules. Continuous formation and accumulation of AGEs also lead to diabetic complications, such as atherosclerosis, diabetic retinopathy, diabetic neuropathy, and diabetic nephropathy (Singh et al., 2014).

Oxidative stress occurs when reactive oxygen species (ROS) and antioxidants are in imbalance state. ROS is one of the free radicals that is involved in molecular and cellular damaging mechanisms, which could lead to various diseases such as diabetes, inflammatory conditions, atherosclerosis, and neurodegenerative diseases (Di Meo et al., 2016). Free radicals may attack free amino groups in long-lived proteins, such as collagen, resulting in the protein with altered covalent bonds. These modified proteins may further glycate to form AGEs (Vistoli et al., 2013). Oxidative stress could also be generated during the second step of the polyol pathway, where sorbitol is converted into fructose by succinate dehydrogenase (Mathebula, 2015). Simultaneously, the oxidised NADPH or NAD ${ }^{+}$ is converted by succinate dehydrogenase into $\mathrm{NADH}$, a substrate for NADPH oxidase. $\mathrm{NADPH}$ oxidase is an enzyme involved in the electron transferring across the plasma membrane to the molecular oxygen (Tarafdar and Pula, 2018). The conversion of NADPH to NADH increases the generation of ROS as well as increasing flux of glucose through the polyol pathway, leading to the production of 3- DG and MGO, these reactive dicarbonyl intermediates or glycation agents are more reactive than reducing glucose in AGE formation (Ashraf et al., 2015).

L. sibiricus is an herbaceous plant species native to China, Mongolia, and Siberia, it is also known as honeyweed or Siberian Motherwort. In Sarawak Malaysia, L. sibiricus is named as Kacangma which has been used as postpartum confinement dish for nursing women. It is effective in activating blood circulation, postpartum haemorrhage., regulating menstrual irregularities, dysmenorrhea, and amenorrhea (Miao et al., 2019). Sayed et al. (2016) reported that the phenolic contents found in L. sibiricus are mainly quercetin, rutin, verbascoside, chlorogenic acid and caffeic acid which have been previously reported to possess anti-glycation and antioxidant activity.

\section{MATERIALS AND METHODS}

\section{Chemicals}

2,2-diphenyl-1-picrylhydrazyl (DPPH), 2-deoxyD-ribose 97\% (Sigma-Aldrich, USA); acetic acid (R\&M，UK); bovine serum albumin (BSA) (Sigma-Aldrich, USA); butylated hydroxytoulene (BHT), chloroform, ethylenediaminetetraacetic acid (EDTA) 99\% (Sigma-Aldrich, USA); ferrozine 98\% (Acros Organic, Belgium); FolinCiocalteu's phenol reagent (Merck, USA); gallic acid 98\% (Acros Organic, Belgium); glacial acid (Riendemann Chmidt Chemical, Malaysia);hydrogen peroxide (Systerm, Malaysia); iron (II), iron (III) chloride (Riendemann Chmidt Chemical, Malaysia); N-1-naphthyl ethylene diamine dihydrochloride (R\&D, UK); potassium ferricyanide (Labjax Chemical Ltd, India); quercitin hydrate (Aldrich Chemistry, USA); Sodium Dodecyl Sulfate (SDS) (Bio-Rad, USA); sodium hydroxide $(\mathrm{NaOH})$, sodium nitroprusside, sulfanilic acid (Merk, USA); Thiobarbituric Acid (TBA), Trichloroacetic Acid (TCA) (Fisher Scientific, USA)

\section{Equipments}

Vortex mixer (LMS Co., Ltd, Japan); Benchtop Centrifuge (Zentrifugen, Germany); $\mathrm{pH}$ meter (Mettler Tolledo, Switzerland); UV-Vis spectrophotometer (SECOMAM, France); Water bath (Memmert, Germany); Electronic balance (Mettler Toledo, Switzerland); FLUOstar Omega Plate Reader (Thermofisher, USA).

\section{Collection of plant materials}

The leaves of $L$. sibiricus were collected from Home Garden Sdn. Bhd. in Kuching, Sarawak. It was identified by a plant taxonomist in Sarawak 
(Anon, 2021). The plant weighing $2 \mathrm{~kg}$ was air dried for one week.

\section{Water extraction of L. sibiricus leaves}

A total of $2 \mathrm{~kg}$ of $L$. sibiricus leaves were ground into powder and soaked in 10 litre of distilled water for 48 hours. With the use of Buchner Funnel Filtration Set and Grade 1 filter paper (11 $\mu \mathrm{m})$, the residues of $L$. sibiricus leaves were filtered and separated from the juice. Freeze dryer was used to evaporate the water content. The plant extract was stored in the freezer at $-18^{\circ} \mathrm{C}$ to prevent the growth of mould.

\section{In vitro antioxidants assay}

\section{DPPH radical scavenging assay}

A DPPH radical scavenging assay method described by Mridula. et al. (2021), with minor modification, was conducted to evaluate the antioxidant activity and quantify the antioxidants that are found in the plant extract. One millimetre of $0.1 \mathrm{mM}$ DPPH dissolved in methanol solution was added to $1 \mathrm{ml}$ of $L$. sibiricus water extract with different concentrations $(10,20,30,40,50,60,70$, 80,90 , and $100 \mu \mathrm{g} / \mathrm{ml}$ ) and vortexed. The reaction mixture was then incubated at room temperature for 30 minutes in the dark. After that, 96 well plate readers were used to measure the absorbance of the reaction mixture at $517 \mathrm{~nm}$ against the blank. Methanol was used as the negative control, while $1 \mathrm{ml}$ of BHT was used as positive control. The percentage of inhibition was calculated in terms of $\mathrm{IC}_{50}$ value. The following equation [1] was used to determine the percentage of radical scavenging activity of each sample.

$$
\% \text { Inhibition }=\frac{(\text { Abs control-Abs sample })}{\text { Abs control }} \times 100 \% \text { [1] }
$$

Where Abs: Absorbance.

\section{Lipid peroxidation (LPO) assay}

Lipid peroxidation assay detects the lipid peroxidation level in the system. Method of LPO assay described by Mridula et al. (2021) was conducted to evaluate the anti-lipid peroxidation of $L$. sibiricus water extract. One millimetre of $L$. sibiricus water extract $(10,20,30,40,50,60,70,80$, 90 , and $100 \mu \mathrm{g} / \mathrm{ml}$ ) and $0.5 \mathrm{ml}$ of $10 \%$ (v/v) egg homogenate were added. The reaction mixture was topped up with $1 \mathrm{ml}$ of distilled water followed by $5 \mu \mathrm{l}$ of $0.07 \mathrm{M} \mathrm{FeSO}_{4}$. The reaction mixture was vortexed for 1 minute and incubated for 30 minutes at room temperature in the dark. After the first incubation, $0.5 \mathrm{ml}$ of $30 \%$ acetic acid, $1.5 \mathrm{ml}$ of $0.8 \% \mathrm{w} / \mathrm{v}$ TBA in $1 \% \mathrm{SDS}$, and $0.5 \mathrm{ml}$ of $20 \%$ TCA were added into the reaction mixture. The reaction mixture was then vortex and incubated for 60 minutes at $95^{\circ} \mathrm{C}$. The mixture was cooled down for 5 to 6 minutes before adding $5 \mathrm{ml}$ of butanol to each of the test tubes, and then centrifuged at $5000 \mathrm{rpm}$ for 60 minutes. The supernatant was pipette out to measure the absorbance at $532 \mathrm{~nm}$. BHT had been used as a positive control while distilled water was the negative control. The results of lipid peroxidation free radicals' inhibition were calculated via equation [1] and expressed in terms of $\mathrm{IC}_{50}$ value.

\section{Chelating capacity assay}

The chelating capacity assay method described by Mridula et al. (2021) with minor modification has been conducted to identify the ability of $L$. sibiricus water extract in interfering the formation of ferrozine- $\mathrm{Fe}^{2+}$ complex in vitro. Firstly, $1 \mathrm{ml}$ of $\mathrm{FeSO}_{4}(0.1 \mathrm{mM})$ and $1 \mathrm{ml}$ of ferrozine $(0.25 \mathrm{mM})$ were added into $1 \mathrm{ml}$ of $L$. sibiricus water extract $(10,20,30,40,50,60,70,80,90$, and $100 \mu \mathrm{g} / \mathrm{ml})$. While the positive control used against the blank solution was EDTA. The reaction mixture was incubated for 10 minutes at room temperature, then the absorbance was measured at $562 \mathrm{~nm}$ with the use of 96 well plate readers. The $\%$ inhibition was calculated using equation [1].

\section{Hydroxyl radical scavenging assay}

Hydroxyl radical scavenging assay described by Rahman et al. (2015) was conducted to estimate the scavenging activity of plant extract by generating the hydroxyl radicals using ascorbic acid-iron EDTA. To $1 \mathrm{ml}$ of phosphate buffer (pH 7.4, $50 \mathrm{mM}), 0.2 \mathrm{ml}$ EDTA $(1.04 \mathrm{mM}), 0.2 \mathrm{ml}$ $\mathrm{FECl}_{3} \cdot \mathrm{H}_{2} \mathrm{O}(20 \mathrm{mM})$, and $0.2 \mathrm{ml}$ of $60 \mathrm{mM}$ deoxyD-ribose were added. Next, $100 \mu \mathrm{l}$ of $L$. sibiricus water extract $(10,20,30,40,50,60,70,80,90$, and $100 \mu \mathrm{g} / \mathrm{ml}$ ) was added into the mixture above. After incubation for 60 minutes at $37^{\circ} \mathrm{C}$ in a water bath, $2 \mathrm{ml}$ of ice-cold TBA and $2 \mathrm{ml}$ of TCA were added into the mixture. The reaction mixture was vortexed and incubated for another 15 minutes at $100^{\circ} \mathrm{C}$. The positive and negative controls were BHT and distilled water, respectively. The reaction mixture was cooled down for about 15 
minutes before measuring the absorbance at 512 $\mathrm{nm}$ and $\%$ inhibition was calculated using equation [1] mentioned above.

\section{Nitric oxide radical scavenging assay}

Nitric oxide is a free radical which can also interact with oxygen and reactive oxygen species (ROS) to generate reactive nitrogen species (RNS). Method described by Mridula et al. (2021) was used in this experiment. A volume of $0.5 \mathrm{ml}$ L. sibiricus water extract $(10,20,30,40,50,60,70$, 80,90 , and $100 \mu \mathrm{g} / \mathrm{ml}$ ) and $1 \mathrm{ml}$ of sodium nitroprusside $(10 \mathrm{mM})$ were added into $0.5 \mathrm{ml}$ of sodium phosphate buffer $(\mathrm{pH} 7.4,0.1 \mathrm{M})$, then vortexed for 5 seconds. $1 \mathrm{ml}$ of sulfanilic acid with $20 \%$ glacial acetic acid was then added into the mixture and incubated for 5 minutes before adding $1 \mathrm{ml}$ of naphthalene. Lastly, incubate the mixture for 30 minutes at $25^{\circ} \mathrm{C}$. In this assay, the blank was sodium phosphate buffer, while positive control is BHT. The absorbance of the reaction mixture was measured at the wavelength at $540 \mathrm{~nm}$ against blank and \% inhibition calculated using equation [1].

\section{Total phenolic content (TPC)}

A volume of $1 \mathrm{ml} \mathrm{L}$. sibiricus water extract (10, 20, $30,40,50,60,70,80,90$, and $100 \mu \mathrm{g} / \mathrm{ml}$ ) was added with $0.5 \mathrm{ml}$ of Folin-Ciocalteu's reagent followed by $0.4 \mathrm{ml}$ of $7.5 \%$ (w/v) sodium carbonate according to the method described by Mridula et al. (2021). The reaction mixture was centrifuged at $3000 \mathrm{rpm}$ for 10 minutes under room temperature, then incubated for another 20 minutes in the dark. The absorbance of the reaction mixture was measured at $765 \mathrm{~nm}$. The total phenolic content of the sample extract $(\mathrm{mg} / \mathrm{ml})$ was expressed in gallic acid equivalent (GAE), where $y$ is absorbance at $760 \mathrm{~nm}$ and $\mathrm{x}$ is total phenolic content in the different extracts. Gallic acid was the positive control in this test.

\section{In vitro AGEs inhibition assay BSA-MGO assay}

Bovine serum albumin-methylglyoxal (BSAMGO) system acts as a marker in the middle stage of oxidative cleavage products formation (Starowicz and Zieliński, 2019). According to the methods described by Sugiura et al. (2017), $1 \mathrm{ml}$ of BSA $(20 \mathrm{mg} / \mathrm{ml})$ and $1 \mathrm{ml}$ of MGO $(60 \mathrm{mM})$ were dissolved separately in $0.1 \mathrm{M}$ of sodium phosphate buffer ( $\mathrm{pH}$ 7.4). After that, $1 \mathrm{ml}$ of $L$. sibiricus water extract $(20,40,60,80$, and 100 $\mu \mathrm{g} / \mathrm{ml})$ is mixed with the BSA-MGO mixture. The mixture was vortexed for 5 seconds and incubated for 5 minutes at $38^{\circ} \mathrm{C}$. After the first incubation, $0.5 \mathrm{ml}(0.2 \mathrm{~g} / \mathrm{L})$ of sodium azide was added into the reaction mixture. The tubes are capped before incubating it for 7 days at $37^{\circ} \mathrm{C}$ in the dark. After 7 days, the absorbance of the reaction mixture was measured with the excitation wavelength at $370 \mathrm{~nm}$ and emission wavelength $420 \mathrm{~nm}$. Reaction mixture without sample was served as negative control while quercetin was the positive control in this assay. The $\%$ inhibition of positive control and sample were calculated by using equation [2].

$\%$ Inhibition $=\frac{\text { Flu negative control group }- \text { Flu test group }}{\text { Flu negative control group }} \times 100 \%[2]$

Where Flu: Fluorescence.

\section{BSA-glucose assay}

The use of BSA-glucose assay was to describe the early stage of AGEs formation (Starowicz and Zieliński, 2019). The procedure is similar as in the BSA-MGO assay, the only different is that the 0.2 $\mathrm{M}$ of sodium phosphate buffer was used to dissolve the BSA and glucose. The \% inhibition of positive control and sample were calculated by using equation [2].

\section{MGO scavenging assay}

Methylglyoxal (MGO) is one of the carbonyl intermediates produced by the degradation of Amadori products during the middle stage of protein glycation. The MGO-scavenging method was described by Sugiura et al. (2017), this activity was carried out to determine whether $L$. sibiricus water extract has MGO-trapping capacity in the middle and advanced stage of AGEs formation. In the experiment, $0.125 \mathrm{ml}$ of MGO and 0.125 $\mathrm{ml}$ of sample $(20,40,60,80$, and $100 \mu \mathrm{g} / \mathrm{ml})$ were added into $0.125 \mathrm{ml}$ of phosphate buffer $(\mathrm{pH} 7.4$, $50 \mathrm{mM}$ ). The reaction mixtures then incubated for $1,2,4$, and 6 hours at $37^{\circ} \mathrm{C}$. After incubation, 0.25 $\mathrm{ml}$ of o-phenylenediamine solution $(50 \mathrm{mM})$ was added into the mixture, then left it for 30 minutes to1 hour at $25^{\circ} \mathrm{C}$ to ensure the $\mathrm{O}$ phenylenediamine to be derivatized. After that, the reaction mixture is quantified under wavelength $349 \mathrm{~nm}$ using POLARstar Omega Multidetection Plate Reader with FP and UV/Vis Spectrometer. Quercetin was being used as 
positive control in this experiment while for negative control, quercetin or plant extract were excluded from the reaction mixture. The \% inhibition of positive control and sample were calculated by using equation [2].

\section{Statistical analysis}

The data were presented in mean \pm standard deviation (SD) in triplicates $(n=3)$. One-way ANOVA was conducted at the significant level of $\mathrm{p}=0.001,0.01$, and 0.05 using IBM SPSS Statistic software, while Multivariate ANOVA was carried out in MGO scavenging assay.

\section{RESULTS}

\section{In vitro antioxidants capacity DPPH radical scavenging assay}

The antioxidant capacity of $L$. sibiricus water extract was investigated via DPPH radical scavenging assay. L. sibiricus water extract showed very strong scavenging effect against $\mathrm{DPPH}$ radical with lower of $\mathrm{IC}_{50}=15.58 \pm 0.05 \mu \mathrm{g} / \mathrm{ml}$ compared to the negative control, $\mathrm{IC}_{50}=132.88$ $\mu \mathrm{g} / \mathrm{ml}\left(\mathrm{p}<0.001 ; \mathrm{p}=1.55 \times 10^{-14}\right)$ However, the $\mathrm{DPPH}$ radical scavenging effect of $L$. sibiricus water extract was significantly $(\mathrm{p}<0.001 ; \mathrm{p}=$ $1.76764 \times 10^{-7}$ ) higher than the standard BHT with $\mathrm{IC}_{50}=3.71 \pm 0.27 \mu \mathrm{g} / \mathrm{ml}$ as shown in Figure $1 \mathrm{~A}$.

\section{Lipid peroxidation assay}

The lipid peroxidation inhibitory effect of $L$. sibiricus water extract was evaluated monitoring Malondialdehyde (MDA) formation. The $\mathrm{IC}_{50}$ value of $L$. sibiricus water extract showed significantly $\left(\mathrm{p}<0.001 ; \mathrm{p}=3.88 \times 10^{-12}\right)$ lower than the negative control, which was $8.32 \pm 0.001$ $\mu \mathrm{g} / \mathrm{ml}$, and $12.04 \mu \mathrm{g} / \mathrm{ml}$, respectively. Standard BHT showed significantly highest $(\mathrm{p}<0.001 ; \mathrm{p}=$ $4.44 \times 10^{-6}$ ) inhibitory effect with the lowest $\mathrm{IC}_{50}$ $=7.63 \pm 0.04 \mu \mathrm{g} / \mathrm{ml}$ as shown in Figure 1B.

\section{Chelating capacity assay}

The metal ion chelating capacity of $L$. sibiricus water extract was evaluated via chelating capacity assay as shown in Figure 2A. L. sibiricus water extract exhibited good metal ion chelation with lower $\mathrm{IC}_{50}=19.96 \pm 0.13 \mu \mathrm{g} / \mathrm{ml}$ compared to the negative control with $\mathrm{IC}_{50}=104.39 \mu \mathrm{g} / \mathrm{ml}$. Standard EDTA had the strongest chelating capacity as it exhibited the lowest $\mathrm{IC}_{50}, 12.62 \pm$ $0.04 \mu \mathrm{g} / \mathrm{ml}$. There was a significant difference $(\mathrm{p}$ $\left.<0.001 ; \mathrm{p}=9.33 \times 10^{-8}\right)$ between the positive control and $L$. sibiricus water extract; as well as between the $L$. sibiricus water extract and negative control $\left(p<0.001 ; p=4.13 \times 10^{-12}\right)$.

\section{Hydroxyl radical scavenging assay}

The $\mathrm{IC}_{50}$ values of standard BHT, L. sibiricus water extract, and negative control are shown in Figure 2B. L. sibiricus water extract showed significantly stronger $(\mathrm{p}<0.001)$ hydroxyl radical scavenging effect with lower $\mathrm{IC}_{50}=10.41 \pm 0.44 \mu \mathrm{g} / \mathrm{ml}$ compared to standard BHT $\left(\mathrm{p}=1.96 \times 10^{-7}\right)$ and the negative control $\left(\mathrm{p}=3.67 \times 10^{-8}\right)$. The $\mathrm{IC}_{50}$ value of BHT was $31.74 \pm 0.24 \mu \mathrm{g} / \mathrm{ml}$ while negative control was $\mathrm{IC}_{50}=38.77 \mu \mathrm{g} / \mathrm{ml}$.

\section{Nitric oxide scavenging assay}

The scavenging effect of $L$. sibiricus water extract against nitrite and nitric oxide radicals was evaluated through nitric oxide scavenging assay. L. sibiricus water extract showed significantly $(\mathrm{p}<$ $\left.0.001 ; \mathrm{p}=5.08 \times 10^{-11}\right)$ lower $\mathrm{IC}_{50}$ value compared to the negative control, which was $\mathrm{IC}_{50}=3.15 \pm$ $0.12 \mu \mathrm{g} / \mathrm{ml}$ and $\mathrm{IC}_{50}=42.57 \mu \mathrm{g} / \mathrm{ml}$, respectively. While, there was a significant $(\mathrm{p}<0.001 ; \mathrm{p}=$ $0.0002)$ different between the BHT $(1.79 \pm 0.12$ $\mu \mathrm{g} / \mathrm{ml})$ and the plant extract as shown in Figure 2C.

\section{Total phenolic content (TPC)}

The TPC assay was conducted to figure out the total amount of phenolic content in the L. sibiricus water extract. At $10 \mu \mathrm{g} / \mathrm{ml}$, the TPC amount of $L$. sibiricus water extract was $6.12 \mathrm{mg} \mathrm{GAE} / \mathrm{g}$ extract, followed by $9.60 \mathrm{mg} \mathrm{GAE} / \mathrm{g}$ extract at concentration $50 \mu \mathrm{g} / \mathrm{ml}$, and lastly $17.19 \mathrm{mg}$ $\mathrm{GAE} / \mathrm{g}$ extract at the highest concentration of $100 \mu \mathrm{g} / \mathrm{ml}$. The results are shown in Table 1 . 
Table 1. Total phenolic content in L. sibiricus water extract.

Concentration of $L$. sibiricus water extract $(\mu \mathrm{g} / \mathrm{ml})$

Total phenolic content of $L$. sibiricus water extract (mg GAE/g extract)

\begin{tabular}{rcc}
10 & 6.12 & 13.60 \\
\hline 50 & 17.19 & 19
\end{tabular}

$\mathbf{A}$

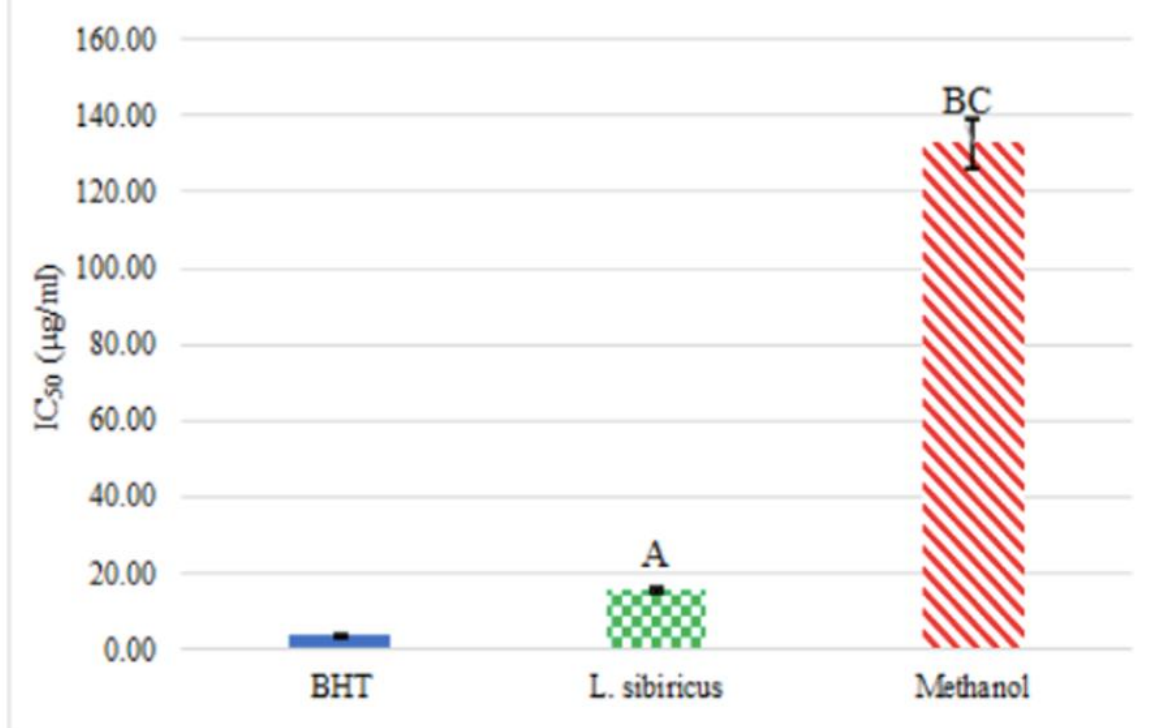

B

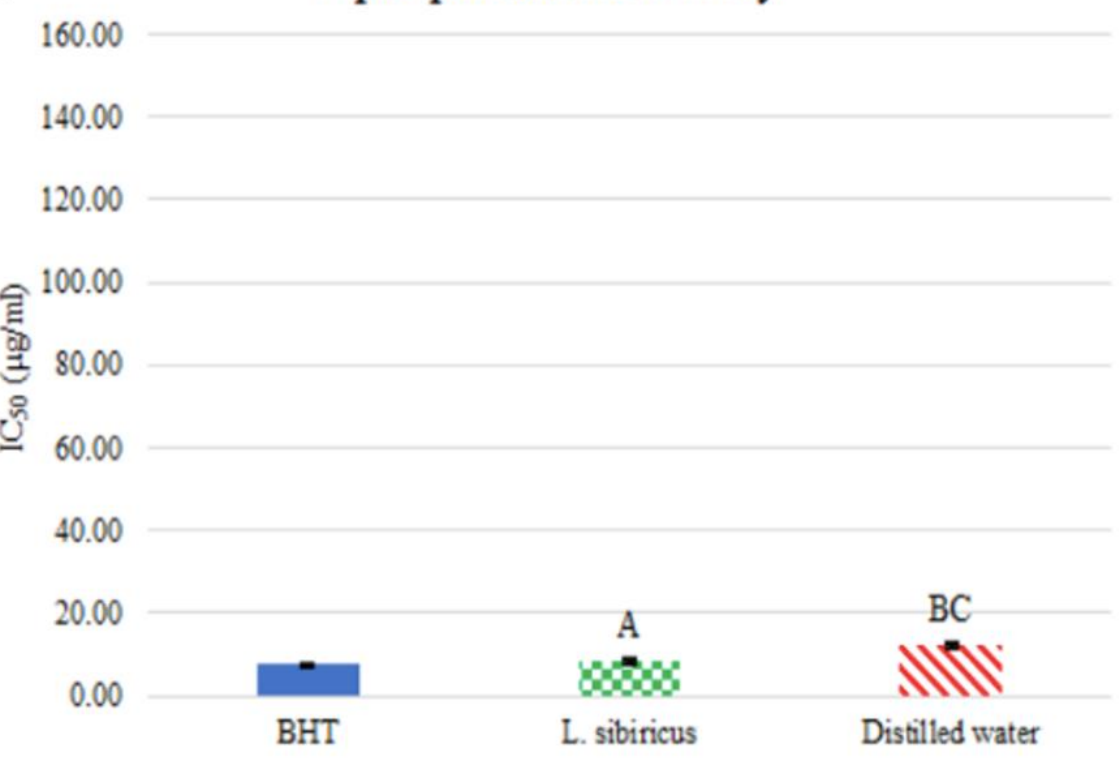

Figure 1. In vitro antioxidant activity of $L$. sibiricus water extract, positive control (BHT) and negative control (methanol and distilled water). (A) DPPH radical scavenging assay; (B) Lipid peroxidation assay. The $\mathrm{IC}_{50}$ values of each compound were expressed in mean \pm standard deviation ( $\mathrm{n}=3$ ). The data was statistically analysed by One-Way Anova. Alphabets A and B denoted that there was a significant different $(\mathrm{p}<0.001)$ between L. sibiricus water extract when compared to the controls, where ${ }^{\mathrm{A}} \mathrm{p}<0.001$ vs positive control and ${ }^{\mathrm{B}} \mathrm{p}<0.001$ vs negative control. While, $\mathrm{C}$ denoted that positive control was significantly different to the negative control ( $\mathrm{P}<0.001$ vs negative control). 


\section{A \\ Chelating capacity assay}

\subsection{0}

140.00

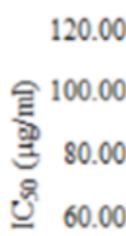

40.00

20.00

0.00

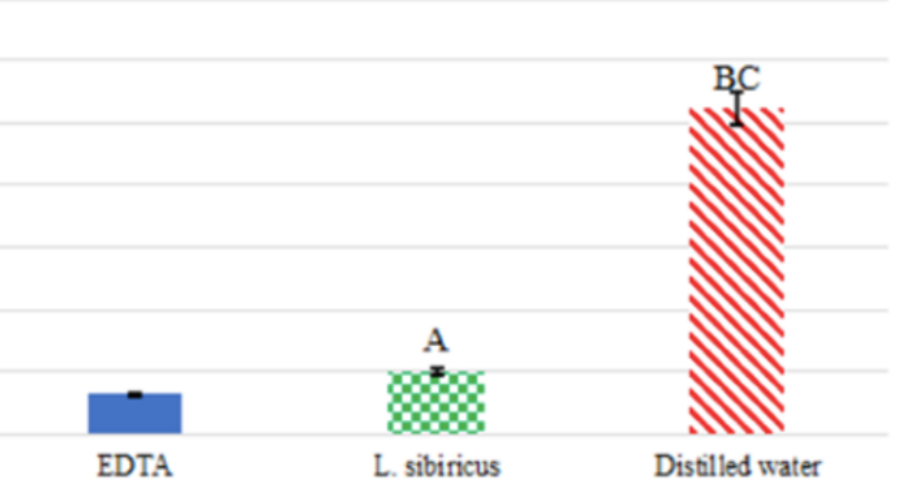

B

160.00

140.00

120.00

\section{刍 100.00}

要 80.00

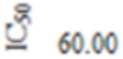

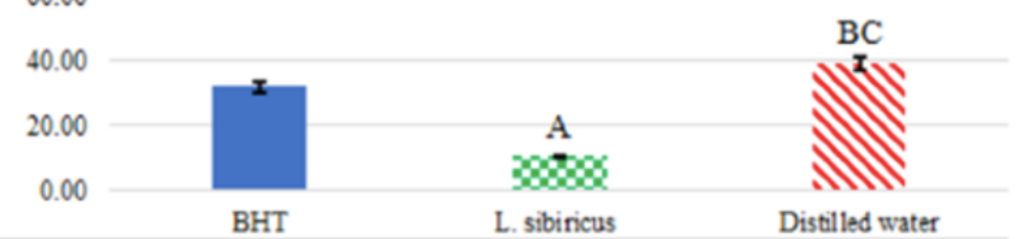

C Nitric oxide radical scavenging assay

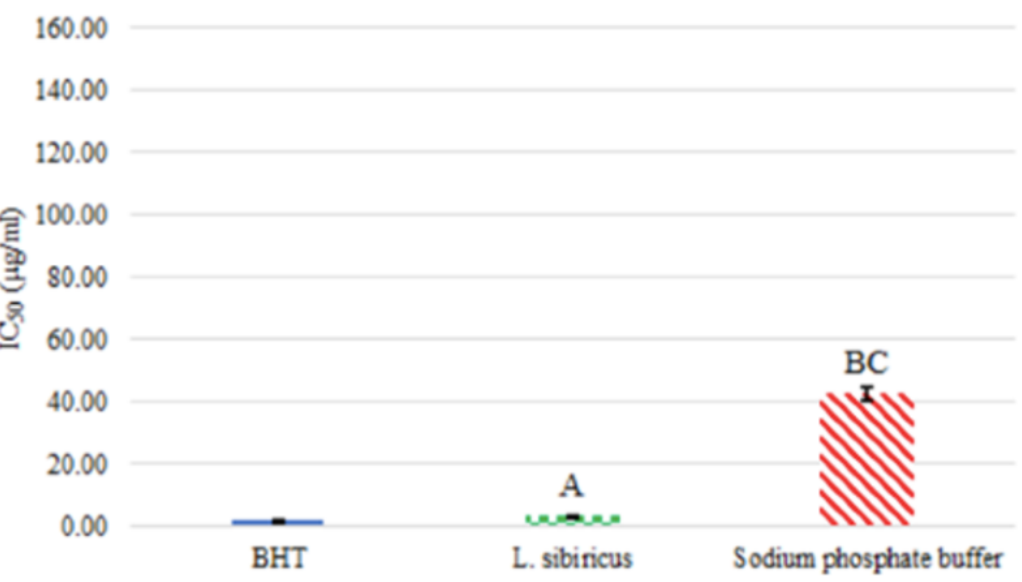

Figure 2. In vitro antioxidant activity of L. sibiricus water extract, positive control (EDTA and BHT) and negative control (distilled water and sodium phosphate buffer). (A) Chelating capacity assay; (B) Hydroxyl $(\mathrm{OH})$ radical scavenging assay; (C) Nitric oxide (NO) radical scavenging assay. The $\mathrm{IC}_{50}$ values of each compound were expressed in mean \pm standard deviation $(\mathrm{n}=3)$. The data was statistically analysed by One-Way Anova. Alphabets $\mathrm{A}$ and $\mathrm{B}$ denoted that there was a significant different $(\mathrm{p}<0.001)$ between $L$. sibiricus water extract when compared to the controls, where ${ }^{A} \mathrm{p}<0.001$ vs positive control and ${ }^{\mathrm{B}} \mathrm{p}<0.001$ vs negative control. While, $\mathrm{C}$ denoted that positive control was significantly different to the negative control ( ${ }^{\mathrm{C}} \mathrm{p}<0.001$ vs negative control). 


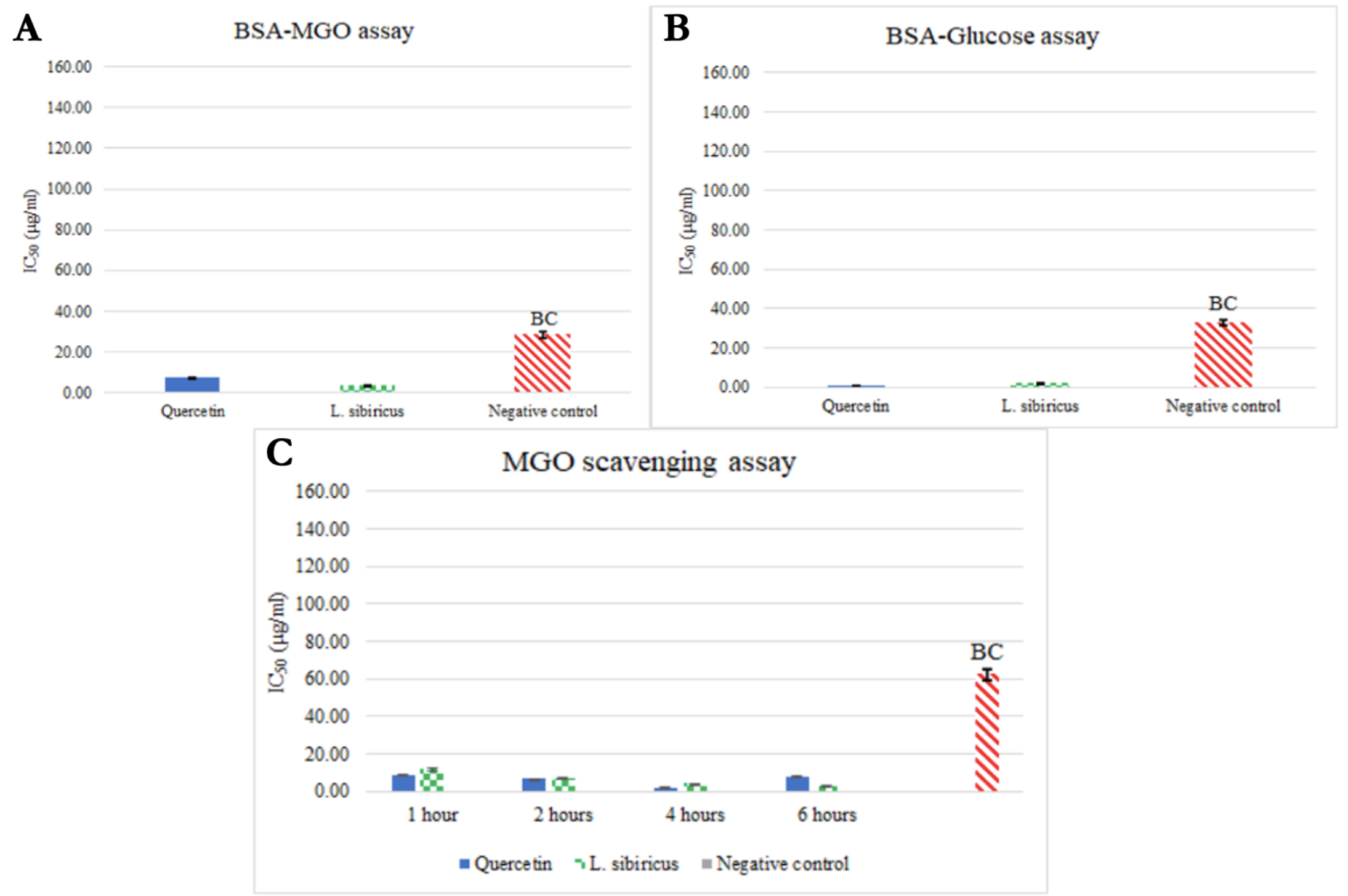

Figure 3. In vitro antiglycation and AGEs inhibitory activity of $L$. sibiricus water extract, standard quercetin, and negative control. (A)BSA-MGO assay; (B) BSA-glucose assay; (C) MGO scavenging assay. The data was statistically analysed by One-Way Anova. ${ }^{A} \mathrm{p}<0.001$ vs positive control and ${ }^{\mathrm{B}} \mathrm{p}<0.001$ vs negative control. While, $\mathrm{C}$ denoted that positive control was significantly different to the negative control ( ${ }^{\mathrm{C}}<<0.001$ vs negative control). 


\section{BSA-MGO assay}

The AGEs inhibitory or antiglycation effects of $L$. sibiricus water extract was evaluated using BSAMGO assay, BSA-glucose assay, and MGO scavenging assay. In BSA-MGO assay, L. sibiricus water extract showed the lowest $\mathrm{IC}_{50}$ when compared to standard quercetin and the negative control, which was $\mathrm{IC}_{50}=3.74 \pm 2.33 \mu \mathrm{g} / \mathrm{ml}, 7.34$ $\pm 0.23 \mu \mathrm{g} / \mathrm{ml}$, and $28.61 \mu \mathrm{g} / \mathrm{ml}$, respectively. The inhibitory effect of $L$. sibiricus water extract was at $\operatorname{par}(\mathrm{p}>0.001, \mathrm{p}=0.057)$ with standard quercetin while significantly different $(p<0.001, p=5.04$ $\times 10^{-5}$ ) to negative control in BSA-MGO assay as shown in Figure 3A.

\section{BSA-glucose assay}

The AGEs inhibitory effect of $L$. sibiricus water extract in BSA-glucose assay was shown in Figure 3B. L. sibiricus water extract exhibited anti-AGE formation $\left(\mathrm{p}<0.001 ; \mathrm{p}=2.36 \times 10^{-7}\right)$ effect with lower $\mathrm{IC}_{50}=2.25 \pm 0.75 \mu \mathrm{g} / \mathrm{ml}$ compared to the negative control of $\mathrm{IC}_{50}=32.93 \mu \mathrm{g} / \mathrm{ml}$. There was no significant difference $(\mathrm{p}>0.001 ; \mathrm{p}=0.55)$ between the effect of the standard quercetin $\mathrm{IC}_{50}$ $=1.05 \pm 0.43 \mu \mathrm{g} / \mathrm{ml}$ and $L$. sibiricus.

\section{MGO scavenging assay}

MGO scavenging assay was conducted to evaluate the MGO trapping effect of $L$. sibiricus water extract. The overall $\mathrm{IC}_{50}$ values of $L$. sibiricus water extract decreased with longer incubation hours as shown in Figure 3C. There was no significant difference in $L$. sibiricus water extract effect compared to standard quercetin $(p>0.001)$ throughout $1(p=0.06), 2(p=0.72), 4(p=0.01)$, and $6(p=0.03)$ hours. At 1 hour incubation, the $\mathrm{IC}_{50}$ of $L$. sibiricus water extract was $11.72 \pm 2.14$ $\mu \mathrm{g} / \mathrm{ml}$, which was higher than the standard quercetin, $\mathrm{IC}_{50}=8.49 \pm 0.10 \mu \mathrm{g} / \mathrm{ml}$. At 2 hours incubation, the $\mathrm{IC}_{50}$ of quercetin and $\mathrm{L}$. sibiricus water extract were $6.64 \pm 0.78 \mu \mathrm{g} / \mathrm{ml}$ and $7.16 \pm$ $2.19 \mu \mathrm{g} / \mathrm{ml}$, respectively. At 4 hours incubation, standard quercetin showed its lowest $\mathrm{IC}_{50}$ in this assay, which was $\mathrm{IC}_{50}=2.10 \pm 1.09 \mu \mathrm{g} / \mathrm{ml}$; while the $L$. sibiricus water extract showed $\mathrm{IC}_{50}=4.15 \pm$ $0.50 \mu \mathrm{g} / \mathrm{ml}$. L. sibiricus water extract exhibited lower $\mathrm{IC}_{50}$ value than the standard quercetin in MGO scavenging assay after 6 hours incubation, which was $3.18 \pm 0.55 \mu \mathrm{g} / \mathrm{ml}$ and $8.29 \pm 2.63$ $\mu \mathrm{g} / \mathrm{ml}$ respectively. Similarly, there was a significant difference $(p<0.001)$ between the $L$. sibiricus water extract and negative control $\left(\mathrm{IC}_{50}=\right.$ $62.56 \mu \mathrm{g} / \mathrm{ml}$ ) throughout 1,2 , 4, and 6 incubation hours $\left(\mathrm{p}=7.85 \times 10^{-12}, 1.66 \times 10^{-6}, 3.48 \times 10^{-9}, 4.81\right.$ $\times 10^{-9}$, respectively).

\section{DISCUSSION}

According to the results, antioxidants interrupt the propagation of free radicals through quenching hydroxyl radical $(\mathrm{OH} \bullet)$ and hydrogen atom donation or electron transferring to the free radicals to produce non-radical molecules, concurring with the statement reported by Romera-Castillo and Jaffé (2015). L. sibiricus water extract showed effective scavenging effects against the free radicals. The in vitro antioxidant activity of $L$. sibiricus water extract maybe includes the quenching of hydroxyl radicals through the donation of electron and chelate ferrous ions at the early stage of Fenton reaction and inhibit the formation of malondialdehyde (MDA) (Figure 2A and $2 \mathrm{~B})$. Excess ferrous ions $\left(\mathrm{Fe}^{2+}\right)$ react with oxygen and hydrogen peroxide $\left(\mathrm{H}_{2} \mathrm{O}_{2}\right)$ to produce ferric ions $\left(\mathrm{Fe}^{3+}\right)$ and $\mathrm{OH} \bullet$ radicals via Fenton reaction (Xu, Wu and $\mathrm{Zhou}, 2020) . \mathrm{OH} \bullet$ radical and $\mathrm{Fe}^{2+}$ induce oxidative degradation on carbonyl or carboxyl groups of deoxyribose sugar in DNA molecules, resulting in lipid peroxidation by damaging mono- and polyunsaturated fatty acids of phospholipid bilayer membrane (Solís-Calero et al, 2015) (Figure 1B). Consequently, a low-weight molecular product called MDA is formed from the degradation of lipids and deoxyribose sugars will increase oxidative stress (Dorsey and Jones, 2017). In this reaction, $\mathrm{Fe}^{2+}$ also acts as a catalyst to enhance the oxidative potential of $\mathrm{H}_{2} \mathrm{O}_{2}$ and other ROS (Ameta et al., 2018). Prevention of intracellular free radicals' production could be used as the treatments and management of free radical-induced diseases, such as cardiovascular diseases, cancer, inflammatory disease and so on (Maddu, 2019). Compounds with high phenolic content has been shown to possess high antioxidant activity. This experiment revealed high total phenolic content in L. sibiricus water extract which may reveal the reason for its high in vitro antioxidant activity (Table 1 ).

Quercetin was used as positive control in the antiglycation assay, which acted as a fine 
substitute to aminoguanidine (AG). This is because quercetin potent in antiglycation than $A G$ in all stages of glycation (Ashraf et al., 2015). L. sibiricus water extract showed strong antiglycation or AGEs inhibitory effects in BSA-MGO, BSAglucose and MGO scavenging assay (Figure 3A, $3 \mathrm{~B}$, and $3 \mathrm{C})$. AGEs are the end products of nonenzymatic glycation between aldose sugars and proteins or lipids, which are catalysed by free radicals to synthesize Schiff bases and Amadori products. Reactive dicarbonyl intermediates from Amadori products react with the amino acids to form AGEs during the advanced stage of glycation. In BSA-MGO and BSA-glucose demonstrated the advanced stage and early stage of glycation, respectively. L. sibiricus water extract exhibited very strong antiglycation (inhibition of AGE formation), the effect was found be like standard quercetin (Figure 3A and 3B). Hence, suggesting it has similar antiglycation mechanisms as the quercetin, which are reducing the amount of Amadori products in the early stage, trapping and scavenge reactive dicarbonyl intermediates, and scavenge free radicals. ROS are produced during the process of AGEs formation too, the imbalance ratio of antioxidants and ROS induce oxidative stress, which may cause complications of diabetes, such as diabetes retinopathy, neuropathy, nephropathy, and strokes.

Sayed et al. (2016) reported that L. sibiricus contains flavonoids, chlorogenic acid and caffeic acid which have been previously reported to possess anti-glycation and antioxidant activity. Flavonoids such as quercetin and rutin play an important role in reducing the formation of Schiff bases and Amadori products through free radicals scavenging. The scavenging effect of flavonoid is contributed by its structure that composed of 2 benzene rings and more than $3-\mathrm{OH}$ groups, which allow them to donate hydrogen atom to free radicals. Thus, aldose sugar is protected from autoxidation and lead to the reduction of Amadori products formation (Yeh et al., 2017). Phenolic compounds also found to scavenge and trap reactive dicabronyl intermediates. Further, phenyl and benzene rings of chlorogenic and caffeic acid consist of hydroxyl groups that increase their electron density to transfer more electrons to free radicals (SUN et al., 2015). Treml and Šmejkal (2016) reported phenyl or benzene rings with three or more -OH groups have better MGO trapping ability than the ones with only 1 or 2 OH groups.

L. sibiricus water extract has similar MGO scavenging effect as standard quercetin (Figure 3C). It scavenged and trapped MGO into adducts, however the adducts yet to be identified. Quercetin has reported to scavenge MGO into two adducts called Que-mono-MGO and Querdi-MGO (Liu et al., 2021). The research conducted by (Liu et al., 2017) investigated that the quercetinMGO adducts have free radical scavenging effects and further trapping the MGO into tri-MGO adducts. The hydroxyl groups in the A ring of flavonoids were suggested to be the active site of trapping MGO (Yang et al., 2017); while (Liu et al., 2017) found out that the hydroxyl groups in B ring of quercetin is the main active site of free radical scavenging.

L. sibiricus water extract may be because of the presences of numerous phytochemical bioactive components which has been previously reported to possess similar effect such as saponins, alkaloids, flavonoids, phenols, tocopherol and diterpenoids. Ashraf et al. (2015) reported that saponins possess chelating activity and could trap ferrous ions before the formation of ferrozine in Haber-Weiss and Fenton reactions. Saponins are also an antiglycation agent that is involved in various steps of glycation and AGEs formation. Research conducted by Chen et al. (2019) reported that saponins reduced the Amadori haemoglobin A1c (HbA1c) level in the early stage of glycation and scavenge free radicals in advanced stage of glycation. Sitarek et al. (2016) reported that flavonoids can be largely found in the leaves, stems and roots of $L$. sibiricus plant, which can modulate the antioxidant genes and thus repair and protect the DNA from oxidative damage. Flavonoids in L. sibiricus extract are also suggested to have antidiabetic effect as it can increase the insulin secretion and proliferation of insulinoma cells (Schmidt et al., 2013).

Alkaloid has been widely found in aerial parts of L. sibiricus plant, especially leonurine which have been reported to stimulate repair and protective effects against cellular DNA oxidative damage by scavenging free radicals and inhibits the formation of ROS (Yang et al., 2018). Sitarek et al. (2016) reported the phenols in L. sibiricus showed antiglycation mechanisms through free radical scavenging, inhibiting the formation of 
ROS, interrupting the dicarbonyl intermediates formation and metal ions chelating. Phytosterol interrupts the non-enzymatic glycation reaction between the protein and reducing sugar, thus suppressing the formation of Amadori products and AGEs (Sheng et al., 2016).

\section{CONCLUSION}

L. sibiricus water extract possesses in vitro antioxidant and antiglycation activity through scavenging or trapping of reactive dicarbonyl intermediates, scavenging free radicals, and reduce oxidative stress. This effect may be due to the presence of bioactive phytochemicals in $L$. sibiricus water extract such as saponins, alkaloids, flavonoids, phenols and phytosterol which have been previously reported to possess antioxidant and antiglycation activities. Further research is ongoing to identify the adducts formed because of scavenge of MGO by L. sibiricus water extract.

\section{ACKNOWLEDGEMENTS}

The authors acknowledge UCSI University for providing the internal funding for this project grant code: CERVIE REIG grant number REIGFAS-2020-031 (Proj-in-FAS-059).

\section{CONFLICT OF INTEREST}

The authors declare there is no conflict of interest in this study.

\section{REFERENCES}

Ameta, R., K. Chohadia, A., Jain, A., \& Punjabi, P. 2018. Fenton and photo-Fenton processes. Advanced Oxidation Processes for Waste Water Treatment. 49-87.

Anon, 2021. Kacangma. [online] Doa.sarawak.gov.my.Available at: $<$ https://doa.sarawak.gov.my/page-0-0-181-Kacangma. html> [Accessed 1 July 2021].

Ashraf, J., Ahmad, S., Rabbani, G., Hasan, Q., Jan, A., Lee, E., Khan, R., Alam, K., \& Choi, I. 2015. 3-Deoxyglucosone: A potential glycating agent accountable for structural alteration in $\mathrm{H} 3$ histone protein through generation of different AGEs. PLOS ONE 10(2): e0116804.

Brings, S., Fleming, T., Freichel, M., Muckenthaler, M., Herzig, S., \& Nawroth, P. 2017. Dicarbonyls and advanced glycation end-products in the development of diabetic complications and targets for intervention. International Journal of Molecular Sciences 18(5): 984.

Cepas, V., Collino, M., Mayo, J., \& Sainz, R. 2020. Redox signaling and advanced glycation endproducts (AGEs) in diet-related diseases. Antioxidants 9(2): 142

Chen, W., Balan, P., \& Popovich, D. 2019. Review of ginseng. antidiabetic, studies. Molecules 24(24): 4501.

Di Meo, S., Reed, T. T., Venditti, P., \& Victor, V. M. 2016. Harmful and beneficial role of ROS. Oxidative Medicine and Cellular Longevity 2016: 1-3.

Dorsey, B. \& Jones, M. 2017. Healthy components of coffee processing byproducts. Handbook of Coffee Processing ByProducts: 27-62.

Liu, G., Xia, Q., Lu, Y., Zheng, T., Sang, S., \& Lv, L. 2017. Influence of quercetin and its methylglyoxal adducts on the formation of $\alpha$-dicarbonyl compounds in a lysine/glucose model system. Journal of Agricultural and Food Chemistry 65(10): 2233-2239.

Liu, P., Yin, Z., Chen, M., Huang, C., Wu, Z., Huang, J., Ou, S., \& Zheng, J. 2021. Cytotoxicity of adducts formed between quercetin and methylglyoxal in PC-12 cells. Food Chemistry 352: 129424

Narendra, M. \& Emad, S. 2019. Diseases related to types of free radicals, antioxidants. IntechOpen. Available from: https://www.intechopen.com/books/antioxidants/diseas es-related-to-types-of-free-radicals.

Mathebula, S. 2015. Polyol pathway: A possible mechanism of diabetes complications in the eye. African Vision and Eye Health 74(1).

Miao, L., Zhou, Q., Peng, C., Liu, Z., \& Xiong, L. 2019. Leonurus japonicus (Chinese motherwort), an excellent traditional medicine for obstetrical and gynecological diseases: A comprehensive overview. Biomedicine \& Pharmacotherapy 117: 109060.

Mridula, S., Siddiqui Masroor, W., Xavier, M., Tan, W., Chan, H., Chirara, K., \& Okechukwu, P. 2021. Antioxidant and antiadvanced glycation end products formation properties of palmatine. Journal of Pharmacy \& Pharmacognosy Research 9(3): 366-378.

Qais, F., Khan, M., Althubiani, A., Al-Ghamdi, S., \& Ahmad, I. 2019. Understanding biochemical and molecular mechanism of complications of glycation and its management by herbal medicine. New Look to Phytomedicine: 331-366.

Rahman, M., Islam, M., Biswas, M., \& Khurshid Alam, A. 2015. In vitro antioxidant and free radical scavenging activity of different parts of Tabebuia pallida growing in Bangladesh. BMC Research Notes 8(1).

Romera-Castillo, C., \& Jaffé, R. 2015. Free radical scavenging (antioxidant activity) of natural dissolved organic matter. Marine Chemistry 177: 668-676.

Sayed, M., Alam, M., Islam, M., Ali, M., Ullah, M., Shibly, A., Ali, M., \& HasanOlive, M. 2016. Leonurus sibiricus L. (honeyweed): A review of its phytochemistry and pharmacology. Asian Pacific Journal of Tropical Biomedicine 6(12): 1076-1080.

Schmidt, S., Jakab, M., Jav, S., Streif, D., Pitschmann, A., Zehl, M., Purevsuren, S., Glasl, S., \& Ritter, M. 2013. Extracts from Leonurus sibiricus L. increase insulin secretion and proliferation of rat INS-1E insulinoma cells. Journal of Ethnopharmacology 150(1): 85-94.

Sheng, Z., Dai, H., Pan, S., Ai, B., Zheng, L., Zheng, X., Prinyawiwatkul, W., \& Xu, Z. 2016. Phytosterols in banana 
(Musa spp.) flowers inhibit $\alpha$-glucosidase and $\alpha$-amylase hydrolysations and glycation reaction. International Journal of Food Science \& Technology 52(1): 171-179.

Singh, V., Bali, A., Singh, N., \& Jaggi, A. 2014. Advanced glycation end products and diabetic complications. The Korean Journal of Physiology \& Pharmacology 18(1): 1.

Sitarek, P., Skała, E., Toma, M., Wielanek, M., Szemraj, J., Skorski, T., Białas, A., Sakowicz, T., Kowalczyk, T., Radek, M., Wysokińska, H., \& Śliwiński, T. 2016. Transformed root extract of Leonurus sibiricus induces apoptosis through intrinsic and extrinsic pathways in various grades of human glioma cells. Pathology \& Oncology Research 23(3): 679-687.

Solís-Calero, C., Ortega-Castro, J., Frau, J., \& Muñoz, F. 2015. Nonenzymatic reactions above phospholipid surfaces of biological membranes: reactivity of phospholipids and their oxidation derivatives. Oxidative Medicine and Cellular Longevity 2015: 1-22.

Starowicz, M. \& Zieliński, H. 2019. Inhibition of advanced glycation end-product formation by high antioxidantleveled spices commonly used in European cuisine. Antioxidants 8(4): 100.

Sugiura, S., Minami, Y., Taniguchi, R., Tanaka, R., Miyake, H., Mori, T., Ueda, M., \& Shibata, T., 2017. Evaluation of antiglycation activities of phlorotannins in human and bovine serum albumin-methylglyoxal models. Natural Product Communications 12(11): $1934578 X 1701201$.

Sun, Y., Gu, J., Tan, X., Wang, C., Jia, X., Feng, L., \& Liu, J. 2015. Curcumin inhibits advanced glycation end product-induced oxidative stress and inflammatory responses in endothelial cell damage via trapping methylglyoxal. Molecular Medicine Reports 13(2): 1475-1486.

Tarafdar, A. \& Pula, G. 2018. The role of NADPH oxidases and oxidative stress in neurodegenerative disorders. International Journal of Molecular Sciences 19(12): 3824.

Treml, J. \& Šmejkal, K. 2016. Flavonoids as potent scavengers of hydroxyl radicals. Comprehensive Reviews in Food Science and Food Safety 15(4): 720-738.

Vlassara, H. \& Uribarri, J. 2013. Advanced glycation end products (AGE) and diabetes: Causes and effects. Current Diabetes Reports 14(1): 453.

Vistoli, G., De Maddis, D., Cipak, A., Zarkovic, N., Carini, M., \& Aldini, G. 2013. Advanced glycoxidation and lipoxidation end products (AGEs and ALEs): An overview of their mechanisms of formation. Free Radical Research 47(sup. 1): 3-27.

Yamagishi, S., Nakamura, N., Suematsu, M., Kaseda, K., \& Matsui, T. 2015. Advanced glycation end products: A molecular target for vascular complications in diabetes. Molecular Medicine 21(S1): S32-S40.

Yang, B., Choi, E., \& Shim, S. 2017. Inhibitory activities of kaempferol against methylglyoxal formation, intermediate of advanced glycation end products. Applied Biological Chemistry 60(1): 57-62.

Yang, L., Qiao, Y., Liu, G., Zhu, X., Luo, Y., Chen, J., Liu, X., Ma, Z., Shang, Y., \& Gu, X. 2018. Effects of dietary supplementation with leonurine hydrochloride on growth performance, immune response, antioxidant capacity and blood parameters in male broiler chicks. Journal of Applied Animal Research 46(1): 1490-1495.

Yeh, W., Hsia, S., Lee, W., \& Wu, C. 2017. Polyphenols with antiglycation activity and mechanisms of action: A review of recent findings. Journal of Food and Drug Analysis 25(1): 84 